\title{
STUDIES ON APHIDIDÆ. I.*
}

\author{
By John J. Davis, \\ OFFicE OF THE STATE ENTOMOLOGist, URBANA, ILL.
}

\section{Myzus elæagni Del Guercio.}

I first found this aphid at Urbana, Ill., November I6, I907, common on the ornamental Russian olive tree (Elæagnus angustifolia). At that time only the sexual forms (wingless oviparous females and winged males) and the jet-black eggs were found, the latter being common on the branches, along and in the axils of the buds. A week later the same species was found on Shepherdia argentea.

Early this year (January ı8, I908) a branch of Elæagnus bearing many eggs was placed in a warm insectary, the branch being placed in water to keep it fresh. These eggs were first noticed hatching February 2, fifteen days after being brought into the warm room, and at about the same time at which the leaf-buds began to expand. (The temperatures, taken with a thermograph at midnight, 6 A. M., noon, and at 6 P. M., gave an average of $59.2^{\circ} \mathrm{F}$. for the period between the time the eggs were brought into the insectary until they commenced hatching.) In the warm insectary, the stem-mothers, or fundatrices, were first observed producing young February i 4, and on February 2 I the first migrants of the second generation were found. These migrants would usually fly from the original food plant immediately upon becoming winged, and this, with the fact that I have never found it on Elæagnus during the summer, and that Professor C. P. Gillette has collected it on thistle, indicates that this aphid has a regular alternate food plant.

Myzus elæagni was first found in Europe and described by Doctor Del Guercio in Il Naturalista Siciliano, Vol. XIII, p. I97 (I894). I have not seen the original description, nor have I examined European specimens, but specimens from Illinois were sent to Doctor Del Guercio, who kindly determined them as his M. elæagni. In the Canadian Entomologist,Vol. XL., p. I 7 (I 908),

* The object of these studies has been to learn the winter histories of littleknown species of Aphididæ, and to describe the various sexual forms heretofore unpublished; also to redescribe species which may have been only briefly described. 
Professor Gillette described this species as M. braggii. His specimens were collected on Canada thistle (Carduus arvensis), and he has since written me that he also collected it this spring (I908) on Elæagnus, and that he had found it on this tree only in the spring previous to July I, which agrees with the observations of Mr. J. T. Monell and myself. Mr. Monell sent me specimens of a Myzus on a hardy Elæagnus which proved to be of the same species as those collected in Colorado and Illinois. These specimens were collected May Io-I3, I907, at St. Louis, Mo., and Mr. Monell writes that he has not found it after that date. This year (I908) I first found winged migrants on Elæagnus at Chicago, Illinois, September I 7 , and each had given birth to several young of the sexual generation.

\section{DESCRIPTION.}

Under the name, Myzus braggii, n. sp., Professor C. P. Gillette has described (Canadian Entomologist, January, I908) the winged male, and winged and wingless viviparous females, and further descriptions of these stages are unnecessary.

"Winged viviparous female, second generation from egg.- (Bred on Elæagnus angustifolia)-Head dusky; on the front and between the bases of the antennæ are a few capitate hairs, and also a conspicuous prominence bearing the cephalic ocellus; the frontal (antennal) tubercles slightly gibbous. (P1. XXI, fig. 6.) Antennæ dusky to black, excepting the two basal segments, which are concolorous with the head; irregularly placed sensoria as follows: 14-39 (usually 25-35), on III., 7-17 on IV., 4-7 on V., and several smaller ones at the distal end of the basal portion of VI.; subequal to the body in length; the first segment gibbous. (P1. XXI, fig. 3.) Eyes dark red. Beak dark at tip, and not reaching beyond the coxæ of the second pair of legs. Thoracic plates light to darker brown. Wings hyaline, the first and second discoidals usually branching at about one half or slightly less, the distance from the margin to the third discoidal. (P1. XXI, fig. 1.) Legs dusky and with a greenish tint, excepting the articulations, which are darker, and the apical ends of the tibiæ and the tarsi, which are black. Abdomen pale greenish, or yellowish green, with a darker quadrangular blotch on the dorsum. Cornicles with the distal third incrassate; pale and almost transparent, excepting the incrassated portion, this being dusky; extending beyond the tip of the abdomen. (P1. XXI, fig. 8.) Style pale and with a greenish tint, more or less ensiform in shape, and about equal to the hind tarsus in length.

Measurements. - The extreme, as well as the averages, from many specimens measured, are given.) Length of body, $1.23-1.52 \mathrm{~mm}$; ; width, 0.472 $0.509 \mathrm{~mm}$.; length of wing, $2.00-2.50 \mathrm{~mm}$.; width, $0.72-0.90 \mathrm{~mm}$.; wing expanse, 4.70-5.60 mm.; antenna, I, 0.0652; II, 0.0489; III, 0.2771-0.4075, average, 0.3317 ; IV, $0.1467-0.2445$, average, $0.2021 ; \mathrm{V}, 0.1304-0.2282$, average, 0.1793 ; VI, basal, 0.0815-0.0978, average, 0.0896; VI, filament, 0.4401-0.6909, average 0.5676 ; average total, $1.4844 ; \mathrm{mm}$. cornicles, $0.2445-0.3586$, average, 0.3015 $\mathrm{mm}$; style, $0.0978 \mathrm{~mm}$; tarsus, $0.0978 \mathrm{~mm}$.

Wingless viviparous female.-(Reared from eggs collected on Elæagnus angustifolia). General body color cream yellow, the thorax and abdomen with two longitudinal rows of more or less oblong, bright green markings. Head with a number of capitate hairs projecting from the front. The two basal segments of the antennæ almost clear transparent or with a slight greenish tint; the others, except the last two segments, which are dusky, are pale green. 
Antennae not more than one half the length of body; borne on gibbous tubercles; the first segment gibbous and with a single capitate hair projecting from the prominence; the articulation between the third and fourth segments absent or indistinct in the specimens reared in the insectary. (P1. XXI, fig. 5.) Eyes dark red. Beak not reaching beyond the coxæ of the middle pair of legs. Coloration of legs as follows: femora light green, tibiæ pale greenish, excepting the tip, which is slightly dusky; tarsi black. The last two segments of the abdomen with a number of capitate hairs projecting caudad. Cornicles almost transparent and with a faint greenish tint, incrassate, and reaching to the tip of the abdomen. Style pale green, and ensiform in shape. (P1. XXI, fig. 7.)

Measurements.-(Averages.) Length of body, $1.6119 \mathrm{~mm}$; width, 0.7898 mm.; antenna, I, 0.0631; II, 0.0368; III and IV, 0.3390; V, 0.1450; VI, basal, 0.0896 ; VI, filament, 0.2445 ; total, $0.9180 \mathrm{~mm}$.; cornicles, $0.3912 \mathrm{~mm}$.; style, $0.1630 \mathrm{~mm}$.; tarsus, $0.0978 \mathrm{~mm}$.

Immature.-The young when first hatched from the eggs are brown, with a slight tint of dull orange, and they very closely resemble the rusty leaf patches, present, at this stage of development, on the Elæagnus leaves. The young of the second instar of this fundatrix generation are pale yellowish green, and of about the same color as the leaves, the latter by this time having lost most of the brownish patches and become more of a solid pale green color. This would appear to be a case of protective resemblance.

Wingless oviparous female.-Head pale green, and bearing a few capitate hairs on the front. Antennæ borne on gibbous tubercles, and the first segments likewise gibbous; dusky, excepting the first two segments and the basal portion of the third, which are pale green; usually reaching to the bases of the cornicles; the usual circular sensorium at the distal end of $V$, and several at the apex of the basal portion of VI; the articulations of the third and fourth segments indistinct, and sometimes invisible. (P1. XXI, fig. 4.) Eyes dark red. Abdomen and thorax of the general dark coloration, having a mottled appearance and consisting of greens, reds, and blacks; and bearing a few capitate hairs. Under magnification there appear three more or less distinct longitudinal lines of this dark color mixture on the dorsum, one on the median line and one on either side; also, the last few segments are solidly of this color. Legs pale green, excepting the articulations and the tarsi, which are dark to black; the basal two thirds of the hind tibiæ swollen and bearing numerous circular sensoria. (P1. XXI, fig. 9.) Cornicles incrassate, and reaching to tip of abdomen; pale green, and darkening at tips. Style ensiform and of a pale dirty-green color.

Measurements.-(Averages.) Length of body, $1.6726 \mathrm{~mm}$.; width, 0.8363 mm.; antenna, I, 0.0652; II, 0.0489; III, 0.2445; IV, 0.1483; V, 0.1597; VI, basal, 0.0880 ; VI, filament, 0.4939 ; total, $1.2405 \mathrm{~mm}$; cornicles, $0.3830 \mathrm{~mm}$.; style, $0.1711 ; \mathrm{mm}$. tarsus, $0.0978 \mathrm{~mm}$.

Young of the first three instars are light green in color, but the immature aphids of the fourth instar are pale yellow with bright green spots scattered over the body in longitudinal rows, as are the dark markings in the adult.

Eggs.-Elliptical oval, greenish-yellow when first deposited and later changing to jet-black, and measuring 0.2443 by $0.5216 \mathrm{~mm}$.

Winged male-- No color notes were made and the following description is taken from specimens mounted in balsam.) Antennæ longer than body; borne on gibbous tubercles; the first segments likewise gibbous; irregularly placed circular sensoria as follows: $24-27$ on III, 9-14 on IV, 2-4 on V, and several at the distal end of the basal portion of VI. (P1. XXI, fig. 2.) Wings hyaline, the first and second discoidals branching about one third, or slightly more than one third, the distance from the margin of the wing to the third discoidal. Cornicles incrassate, and reaching beyond the tip of the abdomen. Style ensiform.

Measurements.-(Average.) Length of body, $1.2089 \mathrm{~mm}$; width, 0.6045 mm.; antenna, I, 0.0652; II, 0.0571; III, 0.4401; IV, 0.3097; V. 0.2553; VI, basal, 0.0978 ; VI, filament, 0.8150 ; total, $2.0402 \mathrm{~mm}$; cornicle, $0.3830 \mathrm{~mm}$.; style, $0.1630 \mathrm{~mm}$; hind tarsus, $0.1141 \mathrm{~mm}$. 


\section{The Barberry Plant-louse (Rhopalosiphum berberidis Kaltenbach)}

Rhopalosiphum berberidis Kalt. was first noted and described as new in this country in I85 I by Asa Fitch, in his "Catalogue of the Homoptera of New York." He later gave the complete life history of the species, under the name of Aphis berberidis Kalt., in the "Tenth Report of the Insects of New York." It has also been mentioned in the writings of Walsh, Thomas, Oestlund, and Hunter, but has never been reported outside of New York.

Mr. J. T. Monell has kindly sent me specimens of this species, collected by him in St. Louis, Mo., and I have frequently found it in Illinois. Mr. Paul Hayhurst writes that he has found it common in Massachusetts.

Fitch reported it from Berberis vulgaris, this being likewise the only known food plant in Illinois. In Europe it was found by Kaltenbach on Berberis vulgaris, and by Buckton on $B$. communis.

I first found this aphid at Urbana, Ill., about the middle of June, I907, on the stems and on the undersides of the leaves of Berberis. It continued to be very abundant until about the first of August, when it became comparatively scarce, although at no time during the entire summer were the plants free from this aphid. During October they again became numerous, and November I 4 I found the sexual forms, although at this time most of them were immature. On this date, eggs also were found, these being deposited in the crevices of the bark and in the grooves between the buds and stem.

This spring (I908) I first examined these plants March i8, and on that date found the eggs all hatched and the reddish-brown immature stem-mothers numerous upon the stems, although the buds had not yet opened. Eggs of a number of other aphids were observed this spring, but those on the Berberis were the first to hatch, the eggs of the other species not hatching until about a week later.

Adult stem-mothers were first noticed March 25, and the first winged adults of the second generation eight days later, April 2. Although most of the second generation became winged, many were wingless upon becoming adult. The immature individuals, as well as the adults of this first generation differ in coloration from the immature and adults of the succeeding generations, as will be seen from the following descriptions 


\section{DESCRIPTIONS.}

Wingless viviparous female, stem-mother-General appearance, to the naked eye, orange. Head and thorax almost entirely bright orange. Antennæ white or nearly so, excepting the tips, which are dusky. Legs concolorous with antennae, excepting the tarsi, which are dark. Abdomen with two lateral, longitudinal stripes of orange, the central dorsum pale greenish or yellowish with longitudinal streaks of orange, the last three abdominal segments entirely orange. Cornicles pale whitish, except the extreme tips. Style orange-yellow. Otherwise as the wingless viviparous females of the succeeding generations, excepting the measurements of the total length and width, the stem-mothers usually being the greater.

The immature stem-mothers (first and second instars) are reddish brown, with dark (almost black) markings, as follows: two longitudinal rows of bars along the median dorsum and only separated by a fine median line of the body color; and two longitudinal rows of spots, one on each of the lateral margins. Head very dark, with a fine median line dividing the dark area into two patches. Antennæ dusky.

The aphids of the fourth instar of the first generation are very similar to the adults in color, except that the markings are not such a bright orange and the body is covered with more or less of a bloom.

Winged viviparous female.-General body color yellow. Antennæ slightly dusky and faintly imbricate; not reaching beyond the bases of the cornicles; segment III subequal to VI (=VI + VII of some authors), segments IV and V subequal and their combined length about equal to that of III, the basal portion and filament of VI subequal; irregularly placed circular sensoria as follows: 18-24 on III, 3-7 on IV, 3-5 on V, and several at the distal end of the basal portion of VI. (P1. XXII, fig. 15.) Eyes appearing black to the naked eye, but under magnification they appear dark-or red-brown. Ocelli brown and distinct upon the yellow back-ground. Wings hyaline; the first and second discoidals branching at about one-third the distance from the margin to the third discoidal. (Pl. XXII, fig. 12.) Legs pale yellowish, except the tarsi and the distal ends of the tibiæ, which are dusky. Abdomen a paler yellow than the head and thorax. Cornicles concolorous with the body, excepting the distal ends, which are often slightly dusky; reaching to or slightly beyond the tip of abdomen; basal third very narrow and the remaining two thirds strongly incrassate, the tips slightly imbricate and flaring. Style concolorous with the body, conical, and slightly more than one third the length of the cornicles. (P1. XXII, fig. 13.)

Measurements.-(Measurements from specimens mounted in balsam.) Length of body, $1.40 \mathrm{~mm}$; width, $0.51 \mathrm{~mm}$; length of wing, $2.8361 \mathrm{~mm}$.; width, $1.0544 \mathrm{~mm}$.; wing expanse, $5.50 \mathrm{~mm}$; antenna, I, 0.0652 ; II, 0.0570; III, 0.3260 ; IV, 0.1847 ; V, 0.1901; VI, basal, 0.1548; VI, filament, 0.1662 ; total, $1.1440 \mathrm{~mm}$. ; cornicles, $0.3423 \mathrm{~mm}$.; style, $0.1385 \mathrm{~mm}$; hind tarsus, $0.1141 \mathrm{~mm}$.

Wingless viviparous female.-(Summer form.) General color bright yellow and often with a slight greenish tint. Antennæ whitish-yellow; the third segment very faintly imbricate and the remaining segments with increasing imbrication; segment III subequal to, or slightly less than, VI (base + filament), IV and $\mathrm{V}$ subequal, and their combined length equal to, or slightly greater than, VI.; about one-half the length of the body; the usual sensorium near the apex of $\mathrm{V}$, and several at the distal end of the basal portion of VI. (P1. XXII, fig. 17.) Eyes red. Legs whitish yellow. Cornicles concolorous with the body; the basal third narrow and the remaining two-thirds strongly incrassate, the tip being more or less flaring; reaching to or slightly beyond the end of the abdomen. (P1. XXI, fig. 11.) Style concolorous with the body, conical, and between one-half and one-third the length of the cornicles.

Measurements.-(Taken from specimens mounted in balsam.) Length of body, $1.5453 \mathrm{~mm}$; width, $0.7817 \mathrm{~mm}$; antenna, I, 0.0652 ; II, 0.0489 ; III, 0.1956 ; IV, 0.1304 ; V, 0.1355; VI, basal, 0.1110; VI, filament, 0.1418 ; total, $0.8284 \mathrm{~mm}$; cornicles, $0.3830 \mathrm{~mm}$; greatest width of cornicles; $0.0896 \mathrm{~mm}$.; style, $0.1548 \mathrm{~mm}$; hind tarsus, $0.1222 \mathrm{~mm}$. 
Wingless oviparous female.-Head pale dirty green and with a median prominence projecting anteriorly. Antennæ dusky and faintly imbricate; one sensorium near the extremity of $\mathrm{V}$, and several at the distal end of the basal portion of VI; placed on frontal tubercles, and the first segment somewhat gibbous; about one-half the length of the body; (P1. XXII, fig. 16.) Eyes black. Beak reaching to the coxæ of the second pair of legs. Dorsum of prothorax almost. entirely covered with a colored patch, the coloration being a mixture of red, brown, and black, intermixed with lighter colors; other thoracic segments with a similar coloration, but the bars of color are broken along the median line. Legs dusky, excepting the basal halves of the femora, which are pale green; the hind tibiæ very noticeably swollen and bearing many circular sensoria. (P1. XXI, fig. 10.) The three anterior segments of the abdomen with markings similar to those on the meso- and metathorax; the remaining segments with darker markings which are more or less contiguous, and appear as a large dark patch on the dorsum. Cornicles green at the bases and becoming dusky at the tips, extending almost to the end of the abdomen; and the distal two-thirds strongly incrassate. Style pale dirty green, conical, and less than half the cornicles in length.

Measurements.-(Taken from specimens mounted in balsam.) Length of body, $2.0798 \mathrm{~mm}$; width, $1.0544 \mathrm{~mm}$; ; antenna, I, 0.0733; II, 0.0570; III, 0.2559 ; IV, 0.1695 ; V, 0.1768 ; VI, basa1, 0.1255; VI, filament, 0.1532 ; total, $1.0112 \mathrm{~mm}$.; cornicles, $0.4352 \mathrm{~mm}$.; style, $0.1793 \mathrm{~mm}$.; hind tarsus, $0.1304 \mathrm{~mm}$.

Eggs.-The elliptical-oval eggs are orange-yellow when first laid, but gradually change to a jet black.

Winged male.-Head black and with gibbous frontal tubercles. Antennæ black, except the two basal segments; reaching beyond the tip of the abdomen; segment I gibbous, III the longest, and the last three more or less imbricate; irregularly placed sensoria as follows: $19-29$ on III, 5-10 on IV, 5-7 on V, and several at the distal end of the basal portion of VI. (P1. XXII, fig. 14.) Eyes black. Thoracic plates black. Wings hyaline and with dark veins; the first and second discoidals branching about one third (sometimes varying to one half) the distance from the margin to the third discoidal. Legs dirty yellow, except the articulations, which are dark, and the tarsi, which are black. Abdomen yellow with black transverse bars, the anterior ones being broken along the median line. Cornicles concolorous with the abdomen and darkening towards the apex, extending beyond the tip of the abdomen; distal two-thirds strongly incrassate, and the tip more or less flaring. Style dusky to black, conical, and slightly longer than the hind tarsus.

Measurements.-(Taken from specimens mounted in balsam.) Length of body, $1.2784 \mathrm{~mm}$.; width, $0.5360 \mathrm{~mm}$; length of wing, $2.5997 \mathrm{~mm}$.; width, $1.0425 \mathrm{~mm}$.; wing expanse, $5.6449 \mathrm{~mm}$.; antenna, I, 0.0652; II, 0.0570; III, 0.4373 ; IV 0.2934 ; V, 0.2836 ; VI, basal, 0.1752 ; VI, filament, 0.2315 ; total, $1.5432 \mathrm{~mm}$.; cornicles, $0.3260 \mathrm{~mm}$.; style, $0.1276 \mathrm{~mm}$.; hind tarsus, $0.1167 \mathrm{~mm}$. Male pupa.-Entire body pale greenish-yellow. Eyes dark red-brown.

\section{The Yellow Clover Plant-louse (Callipterus trifolii Monell).}

This yellow Callipterus is common in all parts of Illinois, living solitary, usually on the undersides of the leaves of red clover (Trifolium pratense). C. trifolii was first described by Mr. J. T. Monell in the Canadian Entomologist, Vol. XIV, p. I4 (I882), from specimens collected in Washington, D. C., June 8, I880. In the literature it has been reported from Iowa (Osborn and Sirrine), and from Delaware (Sanderson). I have received specimens from Mr. Paul Hayhurst, collected in Minnesota, and he writes that he has also found it in Kansas, Minnesota, North Dakota, and Virginia. Mr. Monell writes that he has found it in 
Missouri, and Doctor J. W. Folsom found it on clover in New York, July 22, I 908.

Heretofore it has been stated that individuals of the genus Callipterus always become winged before reproducing viviparously. This characteristic does not always hold true for C. trifolii, for I have found wingless individuals giving birth to young. As a rule, however, most of the young are produced by winged individuals.

\section{DESCRIPTIONS.}

Wingless viviparous female.-General color of body pale green with a faint yellowish tint, and with dusky tubercular spots on the dorsum. Antennae pale whitish green at base, but becoming dusky and black towards the apex; very faintly imbricate, as long as, or slightly longer than, body, 9-12 sensoria in a row on segment III. (P1. XXIII, fig. 30.) Eyes dark red. Beak not reaching beyond the coxæ of the second pair of legs. Legs pale, excepting the joints, which are dusky, and the tarsi, which are black. The six longitudinal rows of tubercles as in winged form, excepting that they are more prominent and bear conspicuous capitate hairs. Cornicles and style as in winged individual.

Measurements.-(From specimens in balsam, collected on Trifolium pratense at Urbana, I11., September 4, 1907.) Length of body, 1.49-1.67, average $1.60 \mathrm{~mm}$; width, 0.72-0.83, average, $0.76 \mathrm{~mm}$; antenna I, 0.076; II, 0.053 ; III, $0.489-0.554$, average, $0.517 ; \mathrm{IV}, 0.326-0.375$, average, $0.347 ; \mathrm{V}, 0.285-0.342$, average, 0.316; VI, basal, $0.146-0.163$, average, 0.156 ; VI, filament, $0.155-0.179$, average, 0.162; total (average) $1.627 \mathrm{~mm}$.; cornicles, $0.062 \mathrm{~mm}$.; style, $0.171 \mathrm{~mm}$. hind tarsus, $0.130 \mathrm{~mm}$.

Winged viviparous female.-General color pale yellowish green, with dusky markings on the dorsum. Antennae concolorous at base and darkening towards apex, longer than body, with 10-12 sensoria in a row on segment III, and faintly imbricate. (P1. XXIII, fig. 29.) Eyes dark red to brown. Beak not reaching to coxæ of second pair of legs. Wings hyaline; veins dark brown to black, with a very narrow border of brownish tint and with a small brown patch at apices of veins, basal half of stigmal vein obsolescent, terminal forks of discoidal branching at a point slightly less than one half the distance from where the discoidal first branches. (P1. XXII, fig. 20.) Legs concolorous with body, excepting tarsi, which are nearly black. Abdomen with six longitudinal rows of dusky tubercles, three rows on each side of the dorsal median. The tubercles of the two rows on each side of the median are oblong, and each tubercle bears two fine setæ. The other tubercles are more or less circular, and each bears but one setæ. Cornicles (P1. XXII, fig. 1) and style (P1. XXII, fig. 21) somewhat dusky, the former tubercular and the latter globular.

Measurements.-(From specimens in balsam, collected on Trifolium pratense at Urbana, I11., August 25 and September 4, 1907.) Length of body, 1.3451.564 , average, $1.454 \mathrm{~mm}$.; width, $0.582-0.691$, average, $0.642 \mathrm{~mm}$.; expanse of wings, $4.654 \mathrm{~mm}$.; length of wing, $2.045 \mathrm{~mm}$.; antenna, I, 0.077 ; II, 0.055 ; III, $0.489-0.538$, average, 0.516 ; IV, $0.358-0.391$, average, $0.368 ; \mathrm{V}, 0.301-0.358$, average, 0.320 ; VI, basal, $0.146-0.179$, average, 0.167 ; VI, filament, $0.146-0.179$, average, 0.162 ; total (average), $1.665 \mathrm{~mm}$; cornicles, $0.066 \mathrm{~mm}$.; style, 0.139 $\mathrm{mm}$; ; hind tarsus, $0.129 \mathrm{~mm}$.

The following table gives comparisons of the average lengths (in millimeters) of the antennal segments of the type specimens, specimens from Mr. Hayhurst and the Illinois specimens. The measurements of the type specimens and of those collected by Mr. Hayhurst were made by Mr. Monell, who has kindly sent them for my use. 


\begin{tabular}{|c|c|c|c|c|c|c|c|c|}
\hline & I & II & III & IV & $\mathrm{V}$ & $\begin{array}{l}\text { VI } \\
\text { basal }\end{array}$ & $\begin{array}{l}\text { VI } \\
\text { fila- } \\
\text { ment }\end{array}$ & $\begin{array}{r}\text { Total } \\
\text { length }\end{array}$ \\
\hline $\begin{array}{l}\text { Monell's Types, Washington, } \\
\text { D. C., June } 8,1880 \ldots \ldots \ldots \ldots\end{array}$ & 0.057 & 0.046 & 0.448 & 0.312 & 0.287 & 0.153 & 0.135 & 1.438 \\
\hline $\begin{array}{l}\text { Hayhurst's Specimens, Arling- } \\
\text { ton, Va., June } 28,1907 \ldots \ldots\end{array}$ & 0.07 & 0.050 & 0.492 & 0.292 & 0.264 & 0.143 & 0.150 & 1.461 \\
\hline $\begin{array}{l}\text { Davis's Specimens, Urbana, } \\
\text { I11., Aug. } 25 \text { and Sept. 4, } \\
1907 \ldots \ldots \ldots \ldots \ldots \ldots \ldots \ldots\end{array}$ & 0.077 & 0.055 & 0.516 & 0.368 & 0.320 & 0.167 & 0.162 & 1.665 \\
\hline
\end{tabular}

Wingless oviparous female.-General color yellow orange, when fully mature. When they first become adult the body is usually entirely yellow, but as the eggs, which are of an orange color, begin to develop within the body they show through the semi-transparent skin and give the orange tint to the body. Head pale yellow. Antennæ, at base, concolorous with head, and darkening towards the apex; not reaching to base of cornicles, and with about 8 or 10 circular sensoria in a row on segment III. (P1. XXIII, fig. 32.) Eyes black. Prothorax pale yellow, meso- and metathorax varying from yellow to orange, according to age since maturity. Legs pale yellowish except tarsi; proximal half of hind tibiæ swollen and with 25 to 40 inconspicuous circular sensoria. (P1. XXIII, fig. 33.) Dorsum of abdomen with longitudinal rows of darkened tubercular spots, three on each side of the median, the spots of the two rows, along the median are oval and usually bear two setæ, arising from conspicuous tubercles, while the spots of the remaining four rows are circular and but one setæ arises from each. Cornicles concolorous and tubercular.

Measurements.-(From specimens in alcohol and balsam, taken on Trifolium pratense at Urbana, I11., November 15 and 26, 1907.) Length of body, 1.636-2.072, average, $1.848 \mathrm{~mm}$.; width, 0.737-0.992, average, $0.864 \mathrm{~mm}$.; antenna, I, 0.070; II, 0.060; III, 0.358-0.473, average, 0.407; IV, 0.179-0.236, average, $0.199 ; \mathrm{V}, 0.179-0.228$, average, 0.207 ; VI, basal, $0.122-0.146$, average, 0.133 ; VI, filament, 0.138-0.147, average, 0.142; total (average), $1.218 \mathrm{~mm}$; cornicles, $0.061 \mathrm{~mm}$, hind tarsus, $0.134 \mathrm{~mm}$.

Egg.-The egg is elliptical, of a bright orange color when first laid, and measures $0.578 \mathrm{~mm}$. in length by $0.252 \mathrm{~mm}$. in width. The average number of eggs found in the abdomens of a number of specimens examined was 10 .

Winged male.-Head and thorax light olive green, abdomen pale yellow green with conspicuous black markings. Antennæ black, excepting two basal segments, as long as body, and with circular sensoria on segments III, IV and V, as follows: $12-15$ in a row on III, $2-4$ on IV, and $3-5$ on V. (Pl. XXIII, fig. 31.) Eyes black. Beak black at tip and not reaching to coxæ of middle pair of legs. Wings hyaline, with dark wing veins slightly margined with brown, and a very small brownish patch at end of each vein; stigmal vein obsolescent; the terminal fork of the discoidal branching at about one half the distance from the margin to where the discoidal first branches. Abdomen with a longitudinal row of large, black, oval spots on each side of the dorsal median line, and each spot bearing one or two very fine setæ; also there is a similar row of smaller setiferous spots on each side, and between these markings and those on the dorsal median are a few scattered and irregularly placed spots. Cornicles tubercular and dusky. Style globular, dusky, and edged with black.

Measurements.- (From four males; two in balsam taken on Trifolium pratense, November 15, 1907, and the others reared in the insectary February 1, 1908, and measured immediately after mounting in balsam.) Length of body, 1.091 (body somewhat shrunken) - 1.382 , average, $1.261 \mathrm{~mm}$; width, 0.509 0.582 , average, $0.536 \mathrm{~mm}$.; expanse of wings, $4.1571 \mathrm{~mm}$.; length of wings, 1.827 mm.; antenna, I, 0.068; II, 0.054; III, 0.472-0.554, average, 0.513 ; IV, 0.277 0.358 ; average, $0.309 ; \mathrm{V}, 0.261-0.318$, average, 0.292 ; VI, basal, $0.138-0.163$, average, 0.153 ; VI, filament, $0.146-0.163$, average, 0.156 ; total, $1.545 \mathrm{~mm}$; cornicles, $0.049 \mathrm{~mm}$; hind tarsus, $0.130 \mathrm{~mm}$. 


\section{The Red-clover Aphis (Aphis bakeri Cowen).}

While examining the base of a red-clover plant (Trifolium pratense) August 5, I907, at Urbana, Ill., I noticed a colony of immature pinkish aphids, which were apparently being attended by the large black ant (Formica fusca L.) The aphids were upon the undersides of the stems close to the ground, and the ants had built a roof-like structure, composed of debris, over the stems, evidently for the protection of the aphids. The young aphids above mentioned were reared to adults and successive generations obtained. In the fall, an infested clover plant was placed in the cold insectary room - this having approximately the outof-door temperature - where it remained until the middle of January, I 9o8. When examined at this date only pupæ were found, and these, when brought into a warm room, became winged and produced young. I have also found this species at Leroy, I11., September 9, on T. pratense, and situated on the plant as were those found at Urbana, but they were attended by another species of ant (Cremastogaster lineolata Say). During I 908 I have found this species very common in fields and along roadways, on $\mathrm{T}$. pratense and attended by several species of ants, namely, Lasius niger var. americanus, and the two species mentioned above. Here the aphids commonly infested the upper parts of the stems and the flowers, as well as the stems near the base.

Several generations were carried through in the insectary, and the following life-history notes taken: The number of young produced by an individual female was found to vary from 6r to 72 , giving an average of 2 to 3 young per day, the largest number of young produced by a single female in one day being 7 . Usually the female lives 6 or 8 days after the birth of the last young.

Because of the pinkish color of the immature individuals and the pseudo-subterranean habit, I determined the species tentatively as Aphis trifolii of Oestlund, which, in the original descriptions was characterized as a subterranean species found on Trifolium repens L., and with a pinkish color, no other definite characteristics being given. I sent specimens to Prof. O. W. Oestlund who examined them and wrote to me that he believed them to be the same species described by him some twenty years ago, and named Aphis trifolii; though he had never seen the adult form before, either spuriæ or migrants, and his original description was based only on the larvæ.

Later, having received specimens of Aphis bakeri Cowen from Prof. C. P. Gillette, I noticed the similarity between these and my 
clover aphis. I accordingly sent Professor Gillette specimens, in regard to which he reported that they "seem to be identical with what we have been calling Aphis bakeri. A. bakeri is not a subterranean species, but it does work close about the bases of the plants, particularly during the colder portions of the year." He also stated that A. cephalicola Cow. was now considered a synonym of $\mathrm{A}$. bakeri, and further that he had collected it on apple and Cratægus as well as on clover.

Last summer (I907) I received specimens of a clover aphis from Mr. Paul Hayhurst, which I determined as A. cephalicola, not knowing at the time that it was a synonym of $\mathrm{A}$. bakeri. These specimens were collected in Minnesota and Mr. Hayhurst has written that he has also taken this species in Kansas and the District of Columbia.

I have used the name of $\mathrm{A}$. bakeri as having priority, inasmuch as the incomplete description of $\mathrm{A}$. trifolii was made from immature individuals only, and we can not be certain that this is the same species; although the pinkish coloration of some of the immature individuals, as well as pseudo-subterranean habit, suggests that they are what was described as A. trifolii.

\section{DESCRIPTIONS.}

Winged viviparous female.-General color black. Head jet black. (P1. III, fig. 23.) Antennæ black, not reaching the cornicles, and with numerous unequal tuberculate sensoria, irregularly placed on segments III, IV, and V, as follows: 22-33 on III, 2-18 on IV and 1-11 on V (usually, however, but the one large distal sensorium on $\mathrm{V}$ ), also several smaller ones at the distal end of the thickened base of VI; segment III usually the longest, but occasionally it is subequal to VI (=VI and VII of some authors), IV slightly shorter than the filament of VI, V about half the length of III, and the basal portion of VI about half the length of IV. (P1. XXIII, fig. 24.) Eyes black. Beak not reaching beyond the coxæ of the middle pair of legs. Thorax jet black. Wings hyaline and with dark veins; the first and second discoidal usually branching at one half the distance from the margin to the third discoidal, this, however, is more or less variable, the distance sometimes being greater, and sometimes less, than one half. (P1. XXIII, fig. 22.) Legs almost entirely black. Abdomen more or less glossy and appearing black to the naked eye. Magnification shows a large, black patch covering most of the dorsum, and two rows of small black spots along the margin, one on each side; the remainder of the dorsum having a greenish tint. The black patch is solid, except one bar anteriorly, and several posteriorly, to it. (Sometimes the dorsal patch, instead of being almost an entire mass, is made up entirely of individual transverse bars.) Cornicles black, imbricated, and more or less flaring at the apex. (P1. XXIII, fig. 26.) Style black, and conical. (P1. XXIII, fig. 27.)

Measurements.-(Many specimens were measured, and the maximum and minimum, as well as the averages, are given. There is considerable variation in the actual measurements of the antennal segments, length of body, etc., between different individuals, but the relative lengths of the antennal segments, length of body, etc., are quite constant.) Length of body, 1.2726-1.8543,

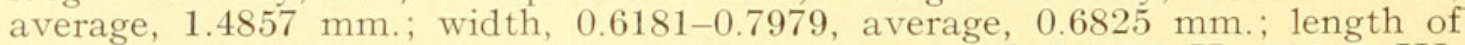
wing, (average) $2.39 \mathrm{~mm}$; width, $0.88 \mathrm{~mm}$.; antenna, I, 0.0682 ; II, 0.0565 ; III, 
$0.2934-0.4564$, average, 0.3328; IV , 0.1548-0.2934, average, $0.1913 ; \mathrm{V}, 0.1222-$ 0.2282 , average, 0.1462; VI, basal, 0.0815-0.1141, average, 0.0986; VI, filament, $0.2119-0.3423$, average 0.2494 ; total (average), $1.1430 \mathrm{~mm}$; cornicles, 0.1032 $\mathrm{mm}$; style, $0.0788 \mathrm{~mm}$; hind tarsus, $0.1059 . \mathrm{mm}$.

Pupa.-Head and thorax with a pinkish tint, and somewhat mottled, or pale green. Eyes black. Tip of beak black. Antennæ pale, excepting the last segment, which is dusky. Wing-pads pale with a greenish yellow tint. Legs pale. Abdomen dirty greenish, and sometimes with a yellowish or pinkish tint. Cornicles and style pale.

Wingless viviparous female.-The general body color, when examined with the naked eye, varying from dirty green or yellowish green to almost jet black. Head and portion of the thorax pale to dark dirty green. Antennæ about one half the body in length; the two basal segments dusky, the third pale, and the remaining segments darkening to black. (P1. XXIII, fig. 25.) Eyes black. Legs, except the articulations and the tarsi, concolorous with the body coloration. Abdomen and posterior portion of the thorax dark dirty green to black green, and covered with many fine dark spots, which are scattered more or less irregularly over the dorsum. Around the cornicles is a semicircular immaculate area, and upon each of the last four abdominal segments is a more or less distinct transverse black band. Ventral surface of the abdomen immaculate, excepting a black blotch at the extreme posterior end. Cornicles pale, imbricate, and slightly flaring at the tips; subequal to the tarsus in length. The dorsally curved style pale, and with a dark margin, conical, and slightly less than the cornicles in length.

Measurements.-Length of body, 1.927-2.218, average, $2.127 \mathrm{~mm}$. : width, 1.136-1.164, average, $1.146 \mathrm{~mm}$; antenna, I, 0.0621; II, 0.0516 ; III, 0.2282 0.3097 , average, 0.2681; IV, 0.1304-0.2119, average, 0.1850; V, 0.1059-0.1630, average, 0.1418; VI, basal, 0.0733-0.0978, average, 0.0912; VI, filament, 0.17930.2526 , average, 0.2192 ; total (average), $1.019 \mathrm{~mm}$; cornicles, $0.1263 \mathrm{~mm}$. ; style, $0.1121 \mathrm{~mm}$; hind tarsus, $0.1141 \mathrm{~mm}$.

Sexual forms-The sexual generation has never been obtained, and from the data above it is evident that this species can hibernate in this latitude as viviparous individuals. Its alternate food plant, the apple, may possibly be the host upon which the sexual forms are produced, though Aphis bakeri has not as yet been found on apple in Illinois.

\section{EXPLANATION OF PLATES.}

Myzus elæagni Del G.-Plate XXI, figs. 1-9.

Figure 1, fore wing; 2, antenna of winged $\sigma^{7} ; 3$, of winged viviparous 0 ; 4 , of wingless oviparous $0 ; 5$, of wingless viviparous $0 ; 6$, head of winged viviparous 우; 7, style of wingless viviparous 우 ; 8 , cornicle of winged viviparous 우; 9 , hind tibia of wingless oviparous 우

Rhopalosiphum berberidis Kalt.-Plate XXI, figs. 10-11; Plate XXII, figs. $12-18$.

Figure 10 , hind tibia of wingless oviparous ㅇ $; 11$, cornicle of wingless vivivarous 우 ; 12 , fore wing; 13 , style; 14 , antenna of winged $\sigma^{7} ; 15$, of winged viviparous 우; 16, of wingless oviparous 우; 17 , of wingless viviparous 우; 18, head of winged viviparous 우

Callipterus trifolii Mon.-Plate XXII, figs. 19-21; Plate XXIII, 28-33.

Figure 19, cornicle of winged viviparous 우; 20, fore wing; 21 , style of winged viviparous $q ; 28$, head of winged viviparous $; ; 29$, antenna of winged viviparous 우; 30, of wingless viviparous 우; 31 , of winged $\sigma^{\top} ; 32$, of wingless oviparous $ᄋ$; 33 , hind tibia of wingless oviparous 우.

Aphis bakeri Cowen.-Plate XXIII, figs. 22-27.

Figure 22, fore wing; 23, head of winged viviparous 0 ; 24, antenna of winged viviparous 우; 25 , of wingless viviparous 우; 26 , cornicle of winged viviparous + ; 27 , style of winged viviparous $ᄋ$. 


\section{$2 \mathrm{BHL}$ Biodiversity Heritage Library}

Davis, John J. 1908. "Studies on Aphididae. I." Annals of the Entomological Society of America 1, 251-261. https://doi.org/10.1093/aesa/1.4.251.

View This Item Online: $\underline{\text { https://www.biodiversitylibrary.org/item/38100 }}$

DOI: https://doi.org/10.1093/aesa/1.4.251

Permalink: https://www.biodiversitylibrary.org/partpdf/193710

\section{Holding Institution}

Smithsonian Libraries

\section{Sponsored by}

Smithsonian

\section{Copyright \& Reuse}

Copyright Status: NOT_IN_COPYRIGHT

This document was created from content at the Biodiversity Heritage Library, the world's largest open access digital library for biodiversity literature and archives. Visit BHL at https://www.biodiversitylibrary.org. 